\title{
MEDITERRANEAN TRADITIONS IN NORTHERN PORTUGUESE ROMANESQUE ARCHITECTURE
}

\author{
M. MALHEIRO \\ Universidade Lusíada Norte-Porto, Portugal. \\ CITAD - Investigation Center in Territory, Architecture and Design, Portugal.
}

\begin{abstract}
'The Mediterranean was the diffuser of ideas and techniques from the remote and rich Orient.' From this statement, written by the geographer Orlando Ribeiro, we understand the cultural changes that have occurred between the North and South of what would be Portugal. The cultural changes derived from contacts that the various migrations caused during the second quarter of the 12th century had important implications on thought, allowing the appearance of the 'national' Romanesque, a nationalized or regionalized synthesis phenomenon, which emerged in northern Portugal. This article is based on the analysis of 58 Romanesque buildings inserted in the basin of River Douro, the old border between the northern Christians and the southern Muslim rule, separating these different worlds. This analysis seeks to highlight the specific constructive tradition of this region, which could articulate multiple identities, where the result is different from the sum of the elements, being considered by many as the most important aspect to be highlighted in the Romanesque of the Sousa, Tâmega and Douro river valleys. The Islamic permanence in the Iberian Peninsula was long, lasting about eight centuries, and natural 'compatible rhythms' coexist between the two arts, population and political realities in this border area. Constructive synthesis derived from a heterogeneous culture in its origins and manifestations, unified by a powerful collective desire, a desire to be together in one place. Thus, the early years of Portuguese Romanesque were not the starting point of an ex nihilo movement and of a sudden revival. An art does not die suddenly to leave the place free for another art to arrive. The article exposes this constructive legacy, owing, in part, to the times in which the border existed, showing the contact points between the two artistic realities and its manifestations in the Romanesque architecture of the region.
\end{abstract}

Keywords: conservation, constructive legacy, Portuguese Romanesque architecture.

\section{INTRODUCTION}

The peculiar decorative thematic and constructive characteristics of some buildings of the river valleys of Sousa and Lower Tâmega, in northern Portugal, define the idiosyncrasies of the Romanesque architecture of the region, which Manuel Monteiro named 'nationalized Romanesque' [1]. This designation is due, in large part, to the miscegenation that the constructions of this patent region forged based on pre-Romanesque tradition, Mozarabic or Visigoth. This article aims at highlighting these features via the analysis of the 58 buildings belonging to the present Romanesque route, composed of parish churches, monasteries, chapels, castles, towers, bridges and memorials. This set of buildings was selected by the Portuguese tutelage entities because they represent the style in the region, extending from the river basins of Sousa, Tâmega and Douro. The theme discussed here, Mediterranean influences in the Portuguese Romanesque architecture, is a topic that has been studied by several authors, interpreted from different perspectives, seeking the source

This paper is part of the Proceedings of the International Conference on Islamic Heritage Architecture and Art (Islamic Heritage Architecture 2016)

www.witconferences.com 
of the influences and the various expressions that the Romanesque of this region presents. It is especially in the valley of River Sousa that the Portuguese historiography identifies a large number of foreign influences, which are reorganized with local pre-existences, to produce a peculiar architecture with a wide range of sculpture. These features spread into the surrounding areas, the basins of Tâmega and Douro, for a long period of time, between the 12th and 14th centuries, suggesting the question raised by Le Goff: '[d]oes history really need to be divided into periods?' [2]. Most of these buildings were built mainly during the 13th century, when Portugal had already stabilized borders and other artistic movements proliferated in the South. Hence, our perspective is not based on the influence of an art by other art via people's contact, but via constructive tradition, something that unconsciously subsisted among the builders of the region. It is this constructive tradition, regionally rooted, that promotes a constructive resurgence of 'archaic' themes, but also allows the incorporation of new themes, almost domesticating them, being a strong feature of the Portuguese architecture. This way of making architecture gains such reputation and prestige that extends to the 13th, 14th and 15th centuries, where new artistic models were also being implanted.

Here we focus on the specific subject theme, unlike many existing isolated references. It assumes the existence of building tradition in the region, before the Romanesque, which undergoes a mixing with the new Romanesque architecture, creating an original architecture with very specific features.

\section{THE PRE-ROMANESQUE CONTEXT}

Going back to earlier than the Middle Ages, we must highlight the fusion that has always occurred between ethnic elements from North and South, merging the population that has emerged within the limits of our current country, in a certain way homogeneous, composed of Celtic and German elements in the North while in the South, predominantly Mediterranean and Berber elements. During the 6th century, the Visigoths invested strongly against the Swabians that, not resisting, allowed the first to take over the entire peninsula, forming a large Christian kingdom. Early in the 8th century, driven by a strong religious impulse, the Arabs (including Syrians, Persians, Egyptians and Berbers) attacked the Peninsula and conquered it. However, as they extended their kingdom, they also lost momentum, and the core of Christian resistance, formed in Asturias, started a countermovement, repelling the enemy. Thus, new Christian kingdoms were formed, including Portugal (Fig. 1).

The Hispanic art in the 7th century, derived from the peace then established by the Visigoths, and arising from the contact with the Byzantines, saw the continuity of the development of a type of religious architecture, featuring cruciform plan churches, considered by some researchers as the best example of the new dynamics imposed by Dume: the church/ mausoleum of S. Frutuoso of Montélios, near the city of Braga, at the north of the region under study. It was built by the 'nobleman and Visigoth' Saint Frutuoso [3] and had the 'idea to travel to the East (...); it is assumed that this idea comes from a letter written to Braulio Zaragoza around the year 651; in it he confesses to find himself isolated and away from cultural centres' [3, p. 63]. M. Monteiro and C.A.F. Almeida advocate a Mozarabic classification for the present existing building, from the post-Visigoth era, of the 9th-10th centuries, becoming a 'pre-Romanesque' building, allowing an understanding of the coming of the Mozarabs from Al-Andalus region.

The art from the time of the Christian Reconquest emerges between two driving forces: the Carolingian renaissance and the emiral Cordoban art. Either one or the other got their 


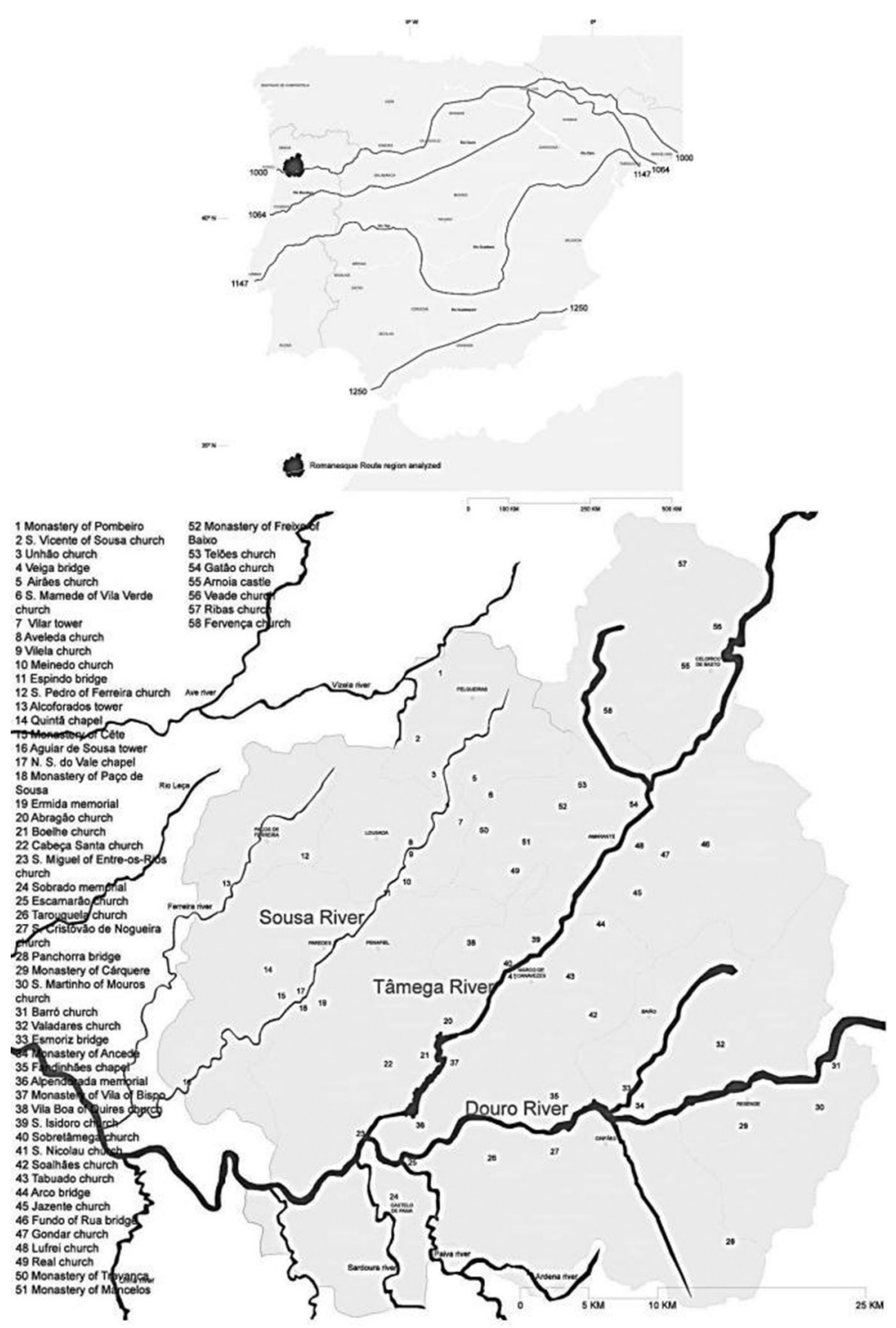

Figure 1: Maps of the Reconquest dates (1) and the localization of the monuments in the region (2).

dynamism from the Byzantine art, based in Constantinople, the most developed phase of the Early Christian art and architecture, being spread by the Arabs, in Europe and North Africa.

The architecture of this time, from the little we know, has some continuity with the previous period, from the northern regions, where churches have differentiated spaces. The interior space of this type of architecture results in limited internal legibility: the space is the product of the multiplication of smaller spaces that can be noticed from the 
outside by existence of small volumes staggered to the centre, meaning that the space is organized from a central core that centralizes others.

Portuguese architecture of that time was influenced by the world-view and the Mozarabic culture, presenting a somewhat cryptic style, with pale signs of classical revival. C.A.F. Almeida argued that it reflected the genius loci and genius tempori, the marks of time and societies that did appear, standing between Cordoban art, emiral and Caliphate (corresponding to the Arab people), and the Asturian architecture (Christian people), and next to the Mozarabic Leonese achievements, expressing features corresponding to this time and this culture. The author 'distinguished many differences between people, both within those consecrated to the religious service as within the secular which practised a liturgy defined by the sense of mystery' [4].

\section{THE MOZARABS}

The region under study, the watershed of the river Douro and its two tributary rivers Sousa and Tâmega, belongs to both domains, the Christian and Islam, during two centuries; being the centre of the country, a 'no man's land', it became a place where exchanges between the two factions occurred. In the 10th century, the opposition between north and south was mitigated by the emigration of Mozarabic people, persecuted by Muslims, heading towards the northern Christian territories, compressing these fertile lands. In addition to the monetary requirements to build monasteries and churches, they also brought with them new construction techniques, water domain and new cultures. Other Mozarabic people followed them, those who were already working as their assistants and who had shown willingness to head on to the Christian lands and work there under their supervision. This was a fundamental fact, as these were the people who began to coordinate all agricultural work and participated in the construction of new buildings such as the monastery of Lardosa in Rans, Anégia, erected by Muzara and Zamora, 'two Mozarabic certainly coming from South' [5] and the primitive Paço of Sousa Monastery at Randulfo Abbot, another Mozarabic who took refuge there, from the south, during the Almanzor raids. This is because, in religious bigotry times, it was important to ensure that at the time of departing, the monastery's monks offered special prayers for their souls, helping them to go to Heaven and not to disappear completely after death, a plan they would never manage to accomplish where they lived. The intercity extensions, as evidenced by the case of S. Frutuoso of Montélios where the Mozarabic dialects became rooted, remained a heavy Christian tradition, in its deepest dimension, that is, the cult of the dead. This happened and extended to the Middle Ages, because people 'to pray for their dead say they believe remission of sins after death' [6].

Coimbra configured to be a significant and cohesive Mozarabic pole under Christian domain, where the northern and southern people lived together, being a resistance stronghold to the novelties brought by the Franks, who at the beginning of the 11th century began to proliferate throughout the north of Portugal and so it remained until the end of the century (Fig. 2).

The late chronology of the Romanesque in the area of the river valleys of Sousa, Tâmega and Douro has to be understood in relation to the precedence of Coimbra's monuments, which were generally built during the second half of the 12th century. Moving builders from the southern zone to the northern area also justifies this dating, as L. Rosas reported, because 'being that the constructions sites of the city of Mondego were already in advance, the need to use manpower became naturally diminished, so their artificers certainly felt the need to search for work elsewhere' [7]. 

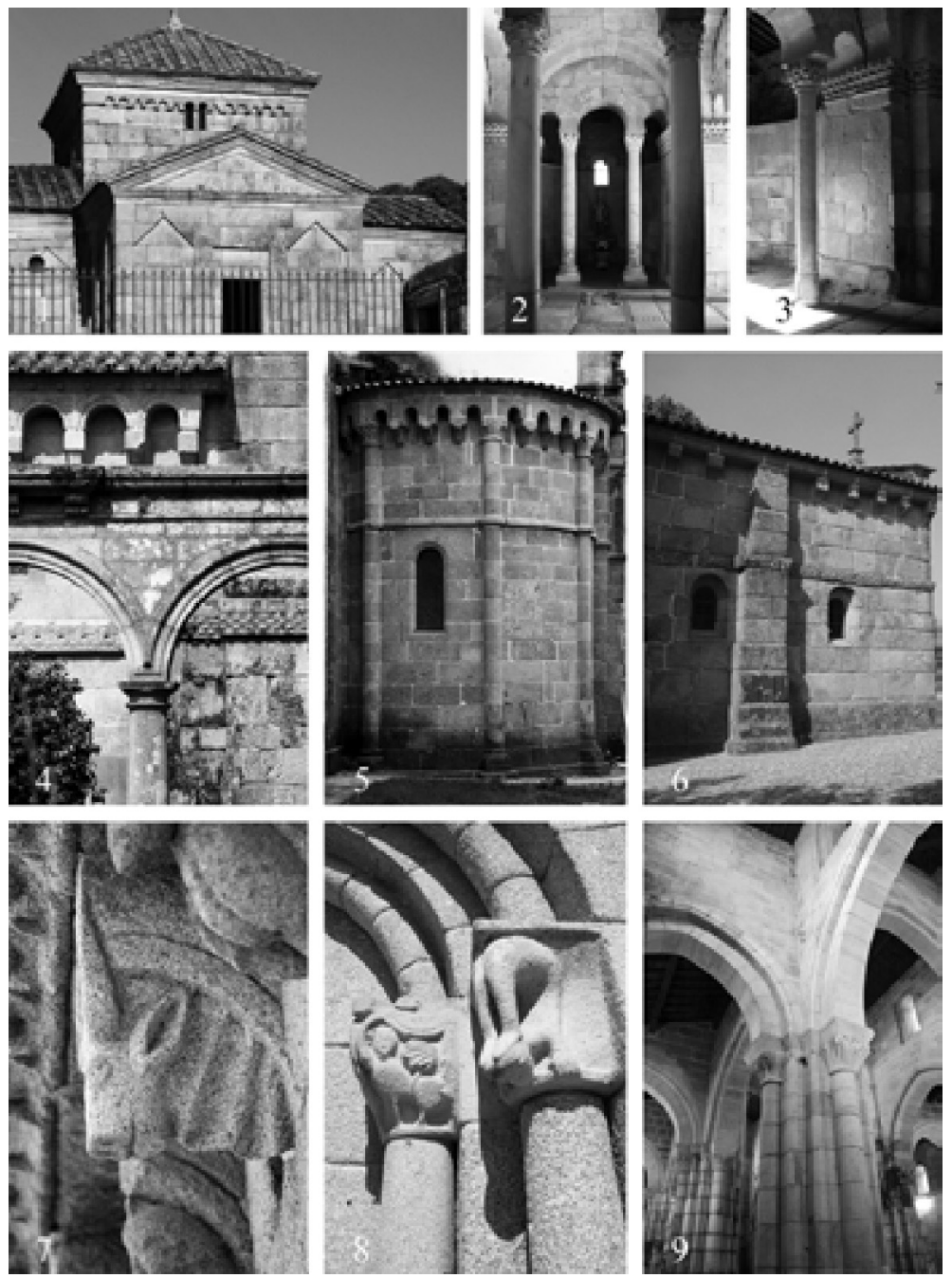

Figure 2: S. Frutuoso de Montélios (1, 2, 3), friezes from Monastery of Paço of Sousa church (4), Monastery of Pombeiro church (5), choir of Abragão church (6), corbeils (7) and chapiters of Cabeça Santa church (8) and diaphragm arches of Monastery of Paço of Sousa church (9).

\section{THE NATIONALIZED ROMANESQUE}

The architecture of the area was influenced by the Mozarabic tradition of Coimbra and French influences of the Porto Cathedral, and Paço of Sousa is a model building where different influences meet. From this building arises the tradition of communicating pre-Romanesque elements with those of other regions. Thus there are buildings of great constructive tradition, like São Vicente de Sousa, Salvador Unhão, Barró, S. Pedro of Ferreira and Cabeça Santa, with influences, especially in the latter, of S. Martinho of Cedofeita in Oporto, with similar chapiters of the chancel arch. These features demonstrate the sense of itinerancy of 
the artistic teams during medieval times, as we have already noted, allowing the 'travel of forms', as Henri Focillon calls them. 'Also the shape of (...) archivolts spheres was certainly directly transmitted from the main entrance of the Old Cathedral (Coimbra) to the Oporto's cathedral and, from here to São Vicente of Sousa. Remember the news relating to a Master Soeiro (Anes), an artist born in Coimbra, which appears documented as having worked in Porto's Cathedral' [8].

In some of the buildings under study, there is the reuse of previous construction elements prior to the existing ones, or recovery techniques and decorative motifs used by earlier times, proving that these were used for a long period of time, which can only mean an appeal to tradition, from which the architecture is done materially and conceptually. This architecture incorporates not only the material conditions of a given place and time, but also the legacy of a specific historical tradition, that even when assimilated, merges with new horizons; a certain cultural legacy is consistently evaluated in confrontation with the various traditions, and this is the dialectical process that makes it possible for art to advance. Thus, the existing innovation process, at the beginning of Portuguese architecture of the Romanesque period, in this sense, is dependent on the review, a reproduction, of a reminder of the tradition, including the tradition of the new, necessarily opposite to the triumph of a universal method, producing things that look like they always were. G. Gaillard recognized it as 'remarkable indigenous character' [9], resulting from the continued use of traditional sculpting techniques and the use of ancient motifs. There seems to be an existence of an autochthonous way of doing with a constructive and decorative know-how, with some Mediterranean fashion. In the only substantive scholarly discussion in English, G. G. King argues that Portuguese churches lack the monumentality of Spanish examples and are in debt to their Islamic or African sources [10].

\subsection{The sculptural motifs}

The most relevant feature in the Romanesque of the Sousa Valley is the sculpture bevel that M. Real refers to as coming from the Oporto region, objectively recognizable at S. Martinho of Cedofeita church, also in the same city. In it there are limestone chapiters of Mozarabic tradition, reused in the triumphal arch, and 'almost a century later copied in granite, in the top of the nave' [11]. This technique is often used to form the sculptural programmes of Romanesque architecture of the Sousa Valley, features described by several authors to be inspired by the chapiters of Cedofeita, but also possibly in line with S. Frutuoso friezes. The same author considers that this sculpture was a 'way for the granite to recover the sharpness of the drawings that migrated from Coimbra and circulated through the Oporto cathedral workshops' [12]. It is a planned sculpting, with almost no volumetry, suggesting more writing on the stone than formation of sculpted images. It is a similar treatment to that given to the bas-relief made of wood, recorded more than modelled, suggesting sometimes the Visigoth or Byzantine art, as referred by R. dos Santos [13].

The Mozarabic motifs, with origin in the 10th-century Islam, improved an art that did not involve icons, based on abstract and geometric manifestations, therefore being the most traditional motifs found in the Romanesque architecture of the region. To these motifs are added up the motifs of the Mozarabic art, coming from the Almoravids of the Al-Andalus in the second half of the 12th century, spread with prevalence of the vegetalist motifs, resulting from a decorative naturalism with usual frequency in the Arab world. The application of these themes in a region dominated by vast green valleys makes perfect sense, as in various churches of the Sousa Valley and Tâmega, especially in the chapiters. The Benedictine rule prevailed in most analysed churches, under the Cluniac spirit. It stipulated that no 
achievement was too beautiful to honour God, which will favour a wealth of aesthetic and ornamental profusion [14]. This manifests itself primarily on the chancel arches and openings of buildings, through which the light and other 'influences' entered [11, p. 47]. We see them applied in the chapiters of the churches of Unhão, S. Vincente of Sousa, Paço of Sousa, Ferreira, Pombeiro, Tarouquela, Travanca, Tabuado, Aveleda and at the choir of Abragão, showing a wide circulation and acceptance of vegetalist themes.

There are also figurative chapiters where animal sculpture, very loyal to the Spanish-Moorish art, with a graceful heraldic expression, comes alive in the approach to the Douro, with pre-Romanesque influence of the Sousa Valley region. The bestiary of Coimbra region arrives with relative purity to the Cabeça Santa church, merging with the themes imported by the
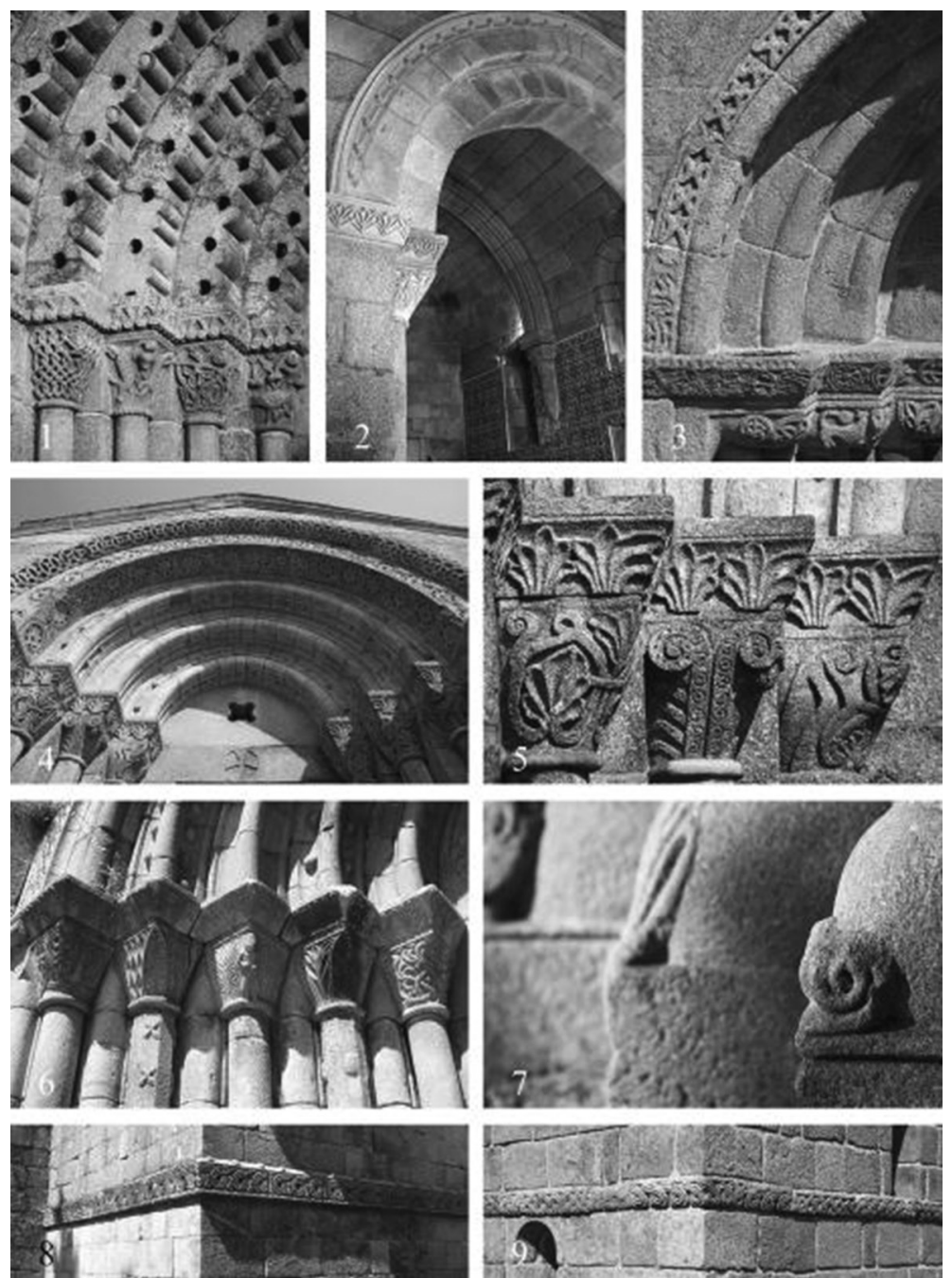

Figure 3: Chapiters from S. Pedro of Ferreira (1), Abragão (2), Boelhe (3), S. Vicente of Sousa (4 and 5), Paço of Sousa (6) churches. Bulbiform bases from Aveleda church (7) and friezes from Monastery of Paço of Sousa (8) and Abragão churches (9). 
Benedictines in Paço de Sousa's workshop, spreading in Unhão and ruralized in Boelhe, demonstrating their appreciation and assimilation in the local language and is fairly considered a national production (Fig. 3).

The friezes, of Proto-Romanesque nature, enfold the exterior elevations and sometimes the interiors, emerging in elevations of Paço de Sousa church with a similar atmosphere to that of the themes of Frutuoso, although smaller, and existing in the original temple, spilling over at the presbytery of Abragão church, the churches of S. Pedro of Ferreira, S. Vicente of Sousa, Unhão, Santo Isidoro and Travanca. The continuous emigration of the Mozarabs to the north prepared the cultural syntheses with the clergy, the nobility and the knights, which several years after the Reconquest headed in the opposite direction, creating a new style, the Gothic, with its specificities. However, in the northern region, most of these themes are extensions, with a 'resistant' Romanesque, until the 16th century. Another common feature that is repeated in several monuments of the region is the use of alternate prismatic column shafts with circular column shafts in supporting archivolts of the portals, both with bulbiform bases, they too suggestive of a pre-Romanesque revival in the region, widespread in the churches of Paço of Sousa, Airães, Aveleda, Boelhe, Cabeça Santa, Cête, Ferreira, Pombeiro, S. Vincente of Sousa and Unhão, that is, most of the churches that make up the analysed group. One of the most fascinating aspects of the Romanesque of the Sousa Valley is the dialect that is established between innovative and traditional solutions, revealing an artistic articulation of great originality. Traditional elements are mostly derived from the Visigoth and Mozarabic culture with a southern fashion that enhances their Mediterranean roots.

\subsection{The architectural space}

The architectural space also denounced the 'invariable', or the use of earlier forms, observing the continuity of using diaphragm arches in the naves of Paço de Sousa church and in the monasteries of Pombeiro and Travanca. These arches are transverse, structuring the walls and serving as support to the roof beams. Its weight is distributed in cruciform pillars, made up of several addorsed columns and half-columns, demarcating the central nave space. The use of the diaphragm arches obscures and divides the space because parts of the nave are more compartmentalized both in height and visually. The resulting compartmentalization is reminiscent of the hierarchical and differentiated spaces of the Visigoth architecture and deeply rooted in the construction of Mozarabic temples, revealing heavily hierarchical and darkened spaces. The return to spaces with specific characteristics of pre-Romanesque churches is noticeable, with a liturgy that unfolded in a mystery ritual, distinctive of the own culture of the Paleo-Christian Basilica. These 'invariables' are also found on the definition of religious spaces such as those seen in the small Church of São Mamede of Vila Verde. It has been built in the late 13th century, as shown by the 'general plan and its volumes, along with the particular architectural and decorative elements, as are the corbels, the crevices and portals with semicircular arc' [15], what L. Fontes considers to be 'a late Romanesque draft rural expression that seem to cross both conservative and progressive influences'. With regard to the conservative influences, one highlights, in this church, the way the space of the chancel and the nave is separated, due to the clear short span of the chancel arch between them, recalling the separation of existing spaces in the Visigoth and Mozarabic time, corresponding to our pre-Romanesque (Fig. 4). This evidence was revealed while conducting surveys, under the supervision of the archaeologist L Fontes, during the study of the church ruins, to support the conservation project coordinated by the team. In the 17 th or 18 th century, this chancel 

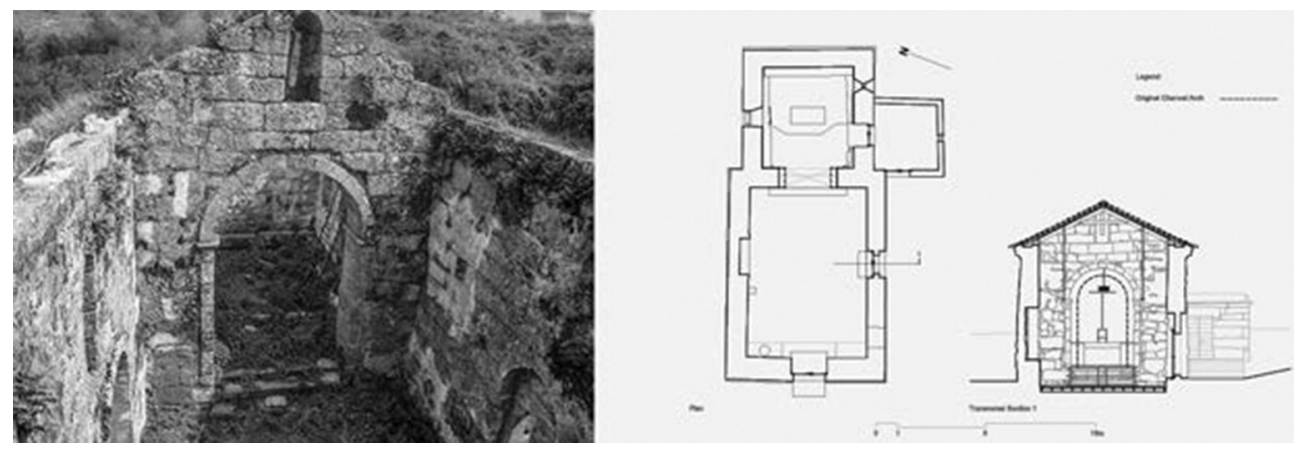

Figure 4: Photo of the chancel arch, plan and section of S. Mamede of Vila Verde church.

arch was augmented in order to adapt to the new Baroque liturgical precepts. Following the same assumption, the Gatão church, built in the late 13th century and beginning of the 14th century, has a chancel which is assumed to be 'an intimate space and safeguarded as a result of the size and scope of the chancel arch, that encloses it in relationship to the nave' [16].

\section{CONCLUSION}

For our purpose, the nomadic character that operis magister, the craftsmen-sculptors and other workers who accompanied them had with several coexisting worlds in the Iberian Peninsula, corresponding in the field of culture and mentality, to the disintegration of the barriers that separated communities until then should be highlighted. The process of acculturation which was the true synthesis of the Portuguese Romanesque architecture emerged at this time, around the final 12th century and the beginning of the 13th century. Therefore, these are the cultural changes that occurred between the north and south of the future country, throughout history, as well as cultural changes that derived from the contacts that the various migrations provided during the second quarter of the 12th century, with important implications in the mind, allowing the appearance of the 'national' Romanesque synthesis phenomenon, nationalized, regionalized or with specific characteristics of this region, because it can articulate multiple identities, where the result is different from the sum of the elements. This is perhaps the most important aspect that should be noted in the Romanesque of this region.

The systematic call to a constructive tradition, visible in the reuse and spread of building systems that were used in earlier times, in the analysed buildings, allows us to advance that an architectural culture based on partially hidden knowledge is emerging, transmitted from generation to generation, offering great resistance to the importation of other cultures, ideologies or other influences, which can only be expressed through ornamentation. The ornamentation in this region has its own features, with a bevelled carving of deep expression, which together with the adaptation of the sculpture to architectural elements, as in the case of corbels, is revealed as one of its main characteristics. The themes of this ornamentation have a rich dialectal fashion, recalling a southern atmosphere, or even the southern peninsula, similar to the Mediterranean climate that the basin of the great Douro river provides, in close proximity of some of the buildings that are part of the analysed group.

Use of ornamentals is restricted to the main elements, such as portals, crevices and corbels supporting the cornices, the arch that separates the nave from the main chapel and friezes, emphasizing its spiritual demarcation value. Thus, the implementation of these buildings in 
predominantly rural areas allows us to conclude that the naturally occurring ornamentation based on foliate or figured motifs is due to the relationship that architecture establishes with the world of life that was directly involved with everyday practices of the population, which was evidenced by this architecture as a characterizing and unifying value of the community. The use of geometric motifs derived from appeals to tradition, especially coming from the Mediterranean scholarly cultures. The most widely used sculptured ornaments are based on vegetable and geometric motifs, and there are some that used human subjects or zoomorphic figures. This allows us to anticipate the existence of stonemasons and travelling craftsmen. However, one can also explain the repetition of these ornamental motifs due to the existence of patterns and sculptural moulds, which regardless of their author travelled from construction sites to construction sites, causing the 'journey of forms,' so evident of the Romanesque of this region. This way of doing architecture is repeated in the history of Portuguese architecture, where later the art style called 'Manueline' - the name of King Manuel (14951521) - demonstrates a 'kind of Mudejar statement, reviving the old Mozarabic tradition ...,' reflecting 'a return to the world of clear and bright forms - cubes and spheres - the common southern and Mediterranean tradition (Muslim and italic at a time)' [17]. There are values throughout the history of Portuguese architecture which are permanent, 'presences more than invariant' [18], and that in one way or another reflect, transmit or continue the specificity of the Portuguese Romanesque architecture.

The intersection with the work of other authors gave another scientific requirement to this text, but what we consider absolutely necessary is to conduct a comprehensive inventory of sculpture and architectural surveys of buildings, for an effective comparison between them and a comprehensive understanding of the various existing schools (including Moorish origin), as well as their evolution in time. The uniqueness of Portuguese Romanesque architecture is intimately linked to its surrounding scenery and local traditions, where the obvious European origin is constantly shaped, adapted and enriched.

\section{ACKNOWLEDGEMENT}

This work is funded by National Funds through FCT - Foundation for Science and Technology under the project UID/AUR/04026/2013.

\section{REFERENCES}

[1] Monteiro, M., Paço de Sousa - O Românico Nacionalizado, In Boletim da Academia Nacional de Belas-Artes, Academia Nacional de Belas Artes: Lisboa, XII, p. 20, 1943.

[2] Le Goff, J., Must We Divided History into Periods? Columbia University Press: New York, Translation 2015.

[3] Fontes, L., A Basílica Sueva de Dume e o Túmulo dito de S. Martinho, Núcleo de Arqueologia da Universidade do Minho \& Junta de Freguesia de Dume: Braga and Dume, p. 22, 2006.

[4] Almeida, C.A.F., História da Arte em Portugal - O Românico, Editorial Presença: Lisboa, p. 33, 2001.

[5] Barroca, M.J., Fortificações e Povoamento no Norte de Portugal (Séc. IX a XI), Portugália, Nova Série: Porto, vol. XXV, p. 182, 1999.

[6] Le Goff, J., Lo maravilloso y lo cotidiano en el Occidente medieval, Gedisa: Barcelona, p. 41, 1991.

[7] Rosas, L., Botelho, L., Resende, N., Rota do Românico, Centro de Estudos do Românico e do Território, Rota do Românico: Lousada, vol. 2, p. 165, 2014. 
[8] Botelho, M.L., A historiografia da arquitectura da época românica em Portugal, Faculdade de Letras da Universidade do Porto, Doctoral dissertation on the history of Portuguese art presented to the Faculty of Arts, University of Porto. Policopied text, Porto, p. 458, 2010.

[9] Almeida, C.A.F., Primeiras Impressões sobre a Arquitectura Românica Portuguesa», Revista da Faculdade de Letras - Série História, p. 76, 1971.

[10] King, G.G., 'Little Romanesque Churches in Portugal' in Medieval Studies in Memory of A. Kingsley Porter, eds Wilhelm Reinhold and Walter Koehler, Harvard University Press: Cambridge, MA, 2 vols, 1, pp. 273-292, 1939.

[11] Real, M.L., O Românico Português na Perspectiva das Relações Internacionais, In Romanico. En Galicia y Porugal. Em Portugal e Galiza, Fundación Pedro Barrié de la Maza/Fundação Calouste Gulbenkian, p. 46, 2001.

[12] Almeida, C.A.F., História da Arte em Portugal: o românico, Publicações Alfa: Lisboa, p. 48, 1986.

[13] Santos, R., Novais, M., O Românico em Portugal, Editorial, Sul: Lisboa, 1955.

[14] Duchet-Suchaux, G., Duchet-Suchaux, M., Les Ordres Réligieux, Flammarion: Paris, 2000.

[15] Malheiro, M., Caetano, J., Fontes, L., Costa, A., São Mamede de Vila Verde, Construir uma igreja com as suas pedras, Centro de Estudos do Românico e do Território: Lousada, p. 63, 2011.

[16] Rosas, L., Botelho, L., Resende, N., Rota do Românico, Centro de Estudos do Românico e do Território, Rota do Românico: Lousada, vol. 1, p. 281, 2014.

[17] Fernandes, J.M., Arquitectura Portuguesa, Imprensa Nacional - Casa da Moeda: Lisboa, p. 34, 1991.

[18] Malheiro, M., A presença da arquitectura. A arquitectura românica do vale do rio Sousa, Doctorate thesis presented to the Department of Urban Planning and Representation of Architecture of the Tecnica Superior School of Architecture of the University of Valladolid, Policopied text, Valladolid, vol. 1, p. 312, 2012. 